\title{
A visszatérő hólyaghurut komplex kezelése
}

\author{
Magyar András dr., Tenke Péter dr. \\ Jahn Ferenc Dél-pesti Kórház és Rendelöintézet, Urológiai osztály, Budapest \\ (osztályvezető: Tenke Péter dr.)
}

\author{
Levelezési cím: \\ Dr. Magyar András \\ 1076 Budapest, \\ Thököly út 21. III/28. \\ E-mail:magyara@gmail.com \\ Tel.: +36 31 783-9686
}

\begin{abstract}
ÖSSZEFOGLALÁS
A hólyaghurut a nők körülbelül felénél jelentkezik legalább egyszer élete során. Hátterében leggyakrabban az Escherichia coli baktérium igazolható. A világszerte rohamosan növekvő bakteriális antibiotikum-rezisztencia egyre nagyobb aggodalomra ad okot, és komoly nehézségeket jelent, különösen a visszatérő hólyaghurut kezelése során. $A z$ utóbbi években számos nemzetközi együttmüködést kezdeményeztek a megfelelő kezelési stratégiák megállapítása céljából. A visszatérő hólyaghurut kezelése kizárólag antibiotikummal hosszú távon a baktériumok rezisztenciájának fokozódásához, a tünetek elhúzódásához, illetve visszatéréséhez vezethet. A rezisztenciakialakulás megakadályozásának legfontosabb módszerei a megfontolt antibiotikum-kezelési stratégiák kidolgozása, a nem antibiotikum-tartalmú gyógyszerekkel történő kezelési és megelőzési módszerek alkalmazása, gyors és megbízható diagnosztikus eszközök bevezetése, a tünetmentes bakteriuria megállapítása és kezelési indikációinak szigorú betartása.
\end{abstract}

\section{KULCSSZAVAK}

VISSZATÉRŐ HÓLYAGHURUT, ANTIBIOTIKUM, REZISZTENCIA, KOMPLEX KEZELÉS, MEGELOZZÉS

\section{Bevezetés}

Az antibiotikumok egészségügyi alkalmazása során a baktériumok rezisztenciájának növekedése elkerülhetetlen, ami az urológiai infekciók szempontjából különösen nagy jelentőséggel bír, hiszen az antibiotikum-felírások 10-15\%-a húgyúti fertózés miatt történik (1). A hólyaghurut az egyik leggyakoribb húgyúti infekció, a nők körülbelül felénél jelentkezik legalább egyszer élete során. Hátterében legtöbbször $E$. coli baktérium igazolható. A gyakori, visszatérő hólyaghurut-epizódok kezelésének sikertelenségéhez jelentősen hozzájárul a világszerte rohamosan növekvő bakteriális antibiotikum-rezisztencia, és bár az akut cystitist sokan banális fertőzésként tartják számon, az esetek felében a kezelés indikációja, a hatóanyag-választás és a kezelési időtartam sem megfelelő (2). Különösen helytelen a visszatérő hólyaghurut kizárólag antibiotikummal történő kezelése és megelőzése, hiszen hosszú

\section{Complex treatment of recurrent cystitis}

\section{SUMIMARY}

About half of the women experience at least one episode of acute cystitis during their lifetime. In acute cystitis the most often isolated causative pathogen is $E$. coli bacteria. The rapid increase in bacterial resistance to antibiotics is a well-known problem, which results in significant difficulties during the treatment of urinary tract infections, especially recurrent acute cystitis. Recently several international cooperation has been initiated to establish the proper treatment strategies. Treatment of recurrent acute cystitis exclusively with antibiotics, in the long term, results in the increase of resistance and prolonged, recurrent symptoms of cystitis. The main strategies to prevent the increase in bacterial antibiotic resistance are prudent antibiotic use, implementation of non-antibiotical modalities for treatment and prevention of recurrent cystitis, development of new, fast, reliable diagnostic tools, diagnosis of asymptomatic bacteriuria and its treatment performed strictly in accordance with the guidelines.

\section{KEYWORDS}

RECURRENT CYSTITIS, ANTIBIOTICS, RESISTANCE, COMPLEX TREATMENT, PREVENTION

távon a rezisztencia fokozódásához, a tünetek elhúzódásához, visszatéréséhez vezethet. Az antibiotikum-kezelési szokások jelentősen befolyásolják a helyi rezisztenciaviszonyok alakulását (3). Összehangolt kezelési stratégiák kidolgozása és széles körű alkalmazása szükséges (4). Ezért alapvetően fontos a helyileg előforduló baktériumok arányának és rezisztenciájának idószakos felmérése, hiszen ezek jelentős időbeli és földrajzi változatosságot mutatnak. Az így nyert ismeretek megalapozzák a húgyúti fertőzések eredményes empirikus kezelését és a sebészeti antibiotikum-profilaxis megtervezését (5). A hólyaghurut antibiotikum-kezelésének sikerességéhez jelentősen hozzájárul továbbá a nem antibiotikum-alapú kezelési és megelőzési módszerek alkalmazása. A jövőben pedig a különböző nem antibiotikum-tartalmú gyógyszerek hatékonyságának felmérése és összehasonlítása céljából további objektív diagnosztikus eszközök bevezetésére lesz szükség (pl. hólyaghurut tüneti kérdőív) (6). 
Célunk a hólyaghurut-kezelés korszerú módszereinek bemutatása és a nem antibiotikum-alapú komplex kezelési stratégiák ismertetése. Cikkünk a legújabb nemzetközi irányelvek, illetve tudományos publikációk ajánlásait és eredményeit foglalja magába (3, 4, 7-9).

\section{A hólyaghurut helyes antibiotikum- kezelési szemlélete}

A széles spektrumú antibiotikumokat célszerú súlyosabb húgyúti fertőzések kezelésére tartogatni. Az akut hólyaghurut-epizódok kezelése során az antibiotikum-kiválasztáskor ügyelnünk kell arra, hogy a lehető legszúkebb spektrumú antibiotikumot alkalmazzuk, ezáltal csökkenthetjük a szélesebb spektrumú antibiotikumokkal szemben kialakuló rezisztenciát (1). Amennyiben a vizelettenyésztés eredménye rendelkezésre áll, úgy célzott antibiotikum-kezelés javasolt. Egyebekben, a hazai bakteriális rezisztenciaviszonyok ismeretében, empirikus kezelésre a legalkalmasabb antibiotikum az egy dózisú foszfomicin-trometamol 3 g, vagy nitrofurantoin 100 mg alkalmazása naponta kétszer, 5 napon keresztül.

A szélesebb spektrumú antibiotikumok a páciensek természetes baktériumflórájára gyakorolt negatív hatásuk és a növekvő bakteriális rezisztencia miatt lehetőség szerint kerülendók. Az amoxicillin/klavulánsav és a cefalosporinok sem javasoltak első választandó szerként, mivel rövid távon kevésbé hatékonyak, továbbá ugyancsak negatív ökológiai hatással bírnak.

Recidív hólyaghurut esetén vizelettenyésztéses vizsgálat elvégzése és komplikáló tényezők, rizikófaktorok keresése szükséges, beleértve a cystokele, illetve a jelentős reziduális vizeletmennyiség, daganat kizárását. A felesleges antibiotikum-használat érdekében célszerű a beteg figyelmét felhívni arra, hogy a következő fellángolás első tüneteinek észlelésekor bőséges folyadékfogyasztás mellett azonnal kezdjen el fitoterápiát (pl. medveszőlőlevél-tartalmú, vény nélküli készítményt). Tájékoztatni kell arról is, hogy jelentkezzen orvosánál, ha tünetei 4 nap után nem javulnak, vagy éppen rosszabbodnak.

\section{A visszatérő hólyaghurut komplex megelőzési szemlélete}

A visszatérő húgyhólyaghurut komplex kezelésének és megelőzésének legfontosabb elemei a betegoktatás, a nem antibiotikum-alapú profilaxis (immunoaktív profilaxis, helyi hormonális kezelés, hüvelyflóra-regenerálás), és csak végső esetben jöhet szóba az antibiotikum-profilaxis. Ezen kívül alapvetően fontos annak helyes megállapítása, mikor alkalmazzunk, és mikor ne alkalmazzunk antibiotikum-kezelést, különös tekintettel az aszimptomatikus bakteriuria esetére, amelynek kezelése csak terhesség és mútéti profilaxis (uroepithel megnyitással járó mútétek) esetén indokolt.

\section{A betegoktatás legyen szerves része a kezelésnek}

A betegoktatás során ismertetnünk kell a föbb rizikófaktorokat, továbbá az elkerülésükre, a komplikációk esélyének csökkentésére és a megelőzésre vonatkozó életmódbeli tanácsokkal is el kell látnunk a betegeket. Fiatalkorban a legfőbb rizikótényezők közé sorolható a szexuális aktus, spermicidek használata, új szexuális partner, visszatérő húgyúti infekciók előfordulása az édesanya anamnézisében, gyerekkori visszatérő húgyúti infekciók és a szekretor vércsoport-státusz. Idősebb korban a legismertebb hajlamosító tényező a menopauza előtti visszatérő húgyúti infekció, inkontinencia, ösztrogénhiány okozta atrófiás vaginitis, cystokele, vizelést követő jelentős vizeletretenció, katéterezés, rendezetlen székelési panaszok és az elhanyagolt általános állapot. A megelőzés szempontjából kiemelendő a betegek személyes higiéniájának szerepe, a folyadékbevitel rendezése, posztkoitális vizelés, székelést követő törlés helyes iránya, esetleges székelési panaszok rendezése, szoros, múszálas alsónemú, tangaalsó viselésének elkerülése. Hangsúlyozni kell a hüvelyflóra-regenerálás fontosságát, azaz az egészséges Lactobacillus-flóra és az enyhén savas hüvelyi pH fenntartását, illetve helyreállítását.

\section{A nem antibiotikum-alapú profilaxis eszközei}

Az életmódbeli változtatásokon kívül kulcsfontosságú jelentőséggel bír a nem antibiotikum-alapú kezelési módszerek bevezetése a visszatérő cystitis epizódjainak csökkentése és a tüneteinek enyhítése érdekében. A hólyaghurut akut fellángolásakor az antibiotikum adása mellett kiegészítő kezelésként, míg megelőzés során önmagukban, vagy kombinációban is alkalmazhatók. A legfontosabb, nem antibiotikum-alapú módszereket és készítményeket az 1. táblázatban foglaltuk össze.

\section{Következtetések}

A húgyúti fertőzések közül az egyik leggyakoribb a heveny hólyaghurut, mely ennek megfelelően jelentős mennyiségú antibiotikum-felírást von maga után (10, 11). Az antibiotikumok gyakori alkalmazása következtében kialakuló bakteriális antibiotikum-rezisztencia komoly aggodalomra ad okot világszerte. Különösen veszélyes a visszatérő húgyhólyaghurut kizárólagosan antibiotikumokkal történő kezelése, amely amellett, hogy károsítja a páciens saját baktériumflóráját, növeli a bakteriális rezisztencia kialakulását. A nem antibiotikum-alapú kezelési és megelőzési stratégiák alkalmazása azon kívül, hogy késleltetheti, megelőzheti a visszatérő hólyaghurut-epizódok jelentkezését, a hólyaghurut tüneteinek súlyosságát is enyhítheti. Ezáltal összességében csökkenthető az antibiotikum-kezelések mennyisége, késleltethető a baktériumok antibiotikum-rezisztenciájának kialakulása (9). 


\section{TÁBLÁZAT: VISSZATÉRŐ hÓlyAghURUT MEGELŐZÉSÉRE ALKALMAS KÉSZÍTMÉNYEK}

\section{Módszerek Készítmények, leírás}

Számos randomizált vizsgálat bizonyította, hogy az OM-89, amely liofilizált Escherichia coli baktérium

1. Immunoak- lizátumot tartalmaz, jelentősen képes csökkenteni a hólyaghurut recidívájának gyakoriságát és időtar-

tív profilaxis tamát. Visszatérő alsó húgyúti fertőzések megelőzésére, akut húgyúti fertőzések kiegészítő kezelésére alkalmas (Evidenciaszint: 1a, Gr.: A) (3).

2. Helyi hormonális kezelés

Menopauzát követően az ösztrogénkészítmények helyi alkalmazása segít megelőzni a visszatérő húgyúti infekciókat. Ezzel szemben az orális hormonális készítmények alkalmazása kerülendő (3)

3. Hüvelyflóra

A bakteriális vaginózis kiküszöbölése, ezáltal a visszatérő húgyúti infekciók megelőzése céljából számos helyreállítása probiotikum (Lactobacillus spp.) készítmény közül választhatunk. Emellett a hüvely savas pH-értékének helyreállítását és a kórokozók kolonizációját gátló kombinációs készítmény (pl.: tejsav, ezüst, C-vitamin) használata is ajánlott.

4. Fitoterápia Számos tőzegáfonyakivonat-tartalmú készítmény áll rendelkezésre, különböző hatóanyag-koncentrációkkal. Az eddigi vizsgálatok ellentmondásos eredményeket mutattak.

Antibiotikum-profilaxis minden egyéb módszer hatástalansága esetén javasolt. Kis dózisban, általában 5. Antibioti- 3-6 hónapig tartó antibiotikum-kezelést jelent naponta, vagy posztkoitálisan, vizelettenyésztés birtokum-profilaxis kában. Nem terhes nőknél profilaxisként alkalmazható antibiotikumok a nitrofurantoin 50 mg, vagy 100 mg naponta, illetve a foszfomicin 3 g tíznaponta (3).

A visszatérő heveny hólyaghurut akut fellángolása során a legoptimálisabb megoldást a korábbi vizelettenyészés alapján történő célzott, szúkebb spektrumú antibiotikum adása jelenti. Antibiotikum választásakor azt is figyelembe kell vennünk, hogy a legtöbb széles spektrumú antibiotikum, mint a fluorokinolonok és a cefalosporinok összefüggésbe hozhatók a Clostridium difficile fertőzések előfordulási gyakoriságának növekedésével (12).

Visszatérő hólyaghurut esetén vizelettenyésztéses vizsgálat és a komplikáló tényezők kizárása szükséges, és különösen fontos a komplex kezelési és megelózési módszerek alkalmazása. A pácienssel ismertetni kell a lehetséges rizikófaktorokat, ki kell emelnünk a személyes higiénia fontosságát. Fitoterápia során biztonsággal alkalmazható készítmények a medveszőlólevél-kivonat és a tőzegáfonya-kivonat. Egyértelmúen bizonyított az OM-89 E. coli liofilizátummal történő immunoaktív profilaxis hólyaghurut recidívát csökkentő hatása (Evidencia szint: 1a, Gr: A). A menopauzát követően hormonális kezelés alkalmazható helyi ösztrogénkészítményekkel. A hüvelyflóra helyreállítására a Lactobacillus spp. probiotikumok mellett a hüvely savas pH-értékének helyreállítására és a kórokozók kolonizációjának gátlására szolgáló kombinációs készítmények is rendelkezésre állnak (pl:: tejsav, ezüst, C-vitamin). Antibiotikum-profilaxis kizárólag minden egyéb módszer hatástalansága esetén alkalmazható (3).

\section{Irodalom}

1. Garau J, Nicolau DP, Wullt B, Bassetti M. Antibiotic stewardship challenges in the management of community-acquired infections for prevention of escalating antibiotic resistance. Journal of global antimicrobial resistance 2014; 2(4): 245-53.

2. Ventola $\mathrm{CL}$. The antibiotic resistance crisis: part 1: causes and threats. $\mathrm{P}$ \& T: a peer-reviewed journal for formulary management. 2015; 40(4): 277-83.

3. Bonkat G PR BR, Bruyère $F$, et al. Urological Infections. In: EAU Guidelines London: European Association of Urology; 2017. p. 857-920.

4. Wagenlehner FM, Bartoletti R, Cek M, et al. Antibiotic stewardship: a call for action by the urologic community. European urology 2013; 64(3): 358-60.

5. Johansen TE, Cek M, Naber KG, et al. Hospital acquired urinary tract infections in urology departments: pathogens, susceptibility and use of antibiotics. Data from the PEP and PEAP-studies. International journal of antimicrobial agents 2006; 28(Suppl 1): S91-107.

6. Magyar AAJ, Pilatz A, et al. The role of the acute cystitis symptom score questionnaire for research and antimicrobial stewardship. Validation of the Hungarian version. Cent European J Urol 2018; 71:doi:10.5173/ ceju.2018.1530 in press.

7. Beerepoot MA, Geerlings SE, van Haarst EP, van Charante NM, ter Riet G. Nonantibiotic prophylaxis for recurrent urinary tract infections: a systematic review and meta-analysis of randomized controlled trials. The Journal of urology 2013; 190(6): 1981-9.

8. Csupor D. Növényi szerek helye a mai gyógyszerkincsben. Gyógyszerészet 2014; 58: 221-223; 226-233.

9. https:/amr-review.org. Tackling drug-resistant infections globally: Final report and recommendations. 2018.03.21.

10. Foxman B. Epidemiology of urinary tract infections: incidence, morbidity, and economic costs. Disease-a-month: DM 2003; 49(2): 53-70.

11. Foxman B, Brown P. Epidemiology of urinary tract infections: transmission and risk factors, incidence, and costs. Infectious disease clinics of North America 2003; 17(2): 227-41.

12. McCusker ME, Harris AD, Perencevich E, Roghmann MC. Fluoroquinolone use and Clostridium difficile-associated diarrhea. Emerging infectious diseases 2003; 9(6): 730-3. 